\title{
Effect Of Grant Palm Oil Ash To The Growth And Production Of Two Corn Varieties (Zea Mays L) In Peatland
}

\author{
Muhammad Arpah, Marlina, Mulono Apriyanto
}

\begin{abstract}
The study, entitled the effect of the administration of Palm Oil Long Palm (AJKS) to the growth and production of two corn varieties in peatlands, was carried out from October 2017 to March 2018 in trench 3 in Tembilahan Hulu Village, Tembilahan Hulu District, Indragiri Hilir Regency, soil analysis and AJKS conducted at the Bogor Institute of Agriculture Laboratory. The purpose of this study was to determine the effect of AJKS administration on the growth and production of two maize varieties (Zea mays $L$ ) on peatlands, and to determine whether there was an interaction between the dosage of AJKS and corn varieties on peat soil ameliorating AJKS. The design used was factorial Randomized Block Design (RBD) using 2 factors with three replications. The first factor is the dose of AJKS administration consisting of 4 levels, namely: A0: $0 \mathrm{~kg} / \mathrm{ha}, \mathrm{A1}: 500 \mathrm{~kg} / \mathrm{ha}, \mathrm{A2}$ : 1000 $\mathrm{kg} / \mathrm{ha}, \mathrm{A3}: 1500 \mathrm{~kg} / \mathrm{ha}$. The second factor is corn varieties with 2 levels, namely: V1: Pioneer Varieties and V2: Varieties N35. Of the two factors above obtained 8 treatment combinations. Based on the results of research that has been done, that there is no real interaction and influence between the treatment of giving AJKS with varieties to all observed parameters. Giving AJKS $1500 \mathrm{~kg} /$ ha gives the highest yields on all parameters observed except for the number of cobs, Pioneer variety is the variety that responds most to AJKS administration.
\end{abstract}

Keywords : naked ash, corn, varieties, peatland

\section{INTRODUCTION}

In Indonesia, corn is an important food source of carbohydrates second only to rice. Corn is also sufficient to be used as food substitute for rice because of the superiority of corn compared to other food commodities is the nutritional content which is higher than rice. Indonesia's natural resources are also very supportive for its cultivation, the price is relatively cheap and the availability of cultivation technology to processing. In addition to food, corn is also efficacious to be used as medicine. Efficacious corn kernels strengthen the lungs, increase appetite and neutralize the heart [1]. Besides that, corn is also used as animal feed (feed) and industrial raw materials and export commodities. The use as feed ingredients which is mostly for broiler chickens is increasing every year. It is estimated that the animal feed industry in Indonesia is able to absorb approximately 200,000 tons of dry shelled corn every month, for this reason it is necessary to increase corn production by using superior varieties followed by optimum fertilizing doses and good farming methods. To meet the needs of the land it is necessary to do agricultural extensification, the lack of available land today causes the need to be extended to land that was once considered marginal land such as peatlands. Some of the weaknesses of peat soils that are often encountered are: (1) the reaction of soils is classified as very acidic from various organic acids formed during weathering, (2) low macro and micro nutrient content, (3) high cation exchange capacity, whereas base saturation low so that the $\mathrm{Ca}, \mathrm{Mg}$ and $\mathrm{K}$ cations are difficult to be available to plants (4) the content of high organic soil acids which directly affect and can poison plants, especially phenolic acids, (5) poor water system [2].

- Muhammad Arpah. Universitas Islam Indragiri. E-mail: arpah6@gmail.com

- Marlina. Universitas Islam Indragiri, E-mail: marlinaunisi@gmail.com

- Mulono Apriyanto. Universitas Islam Indragiri. E-mail mulonoapriyanto71@gmail.com
Plant cultivation on peatlands needs appropriate technology and soil management that leads to improved drainage and aeration both through soil management and the provision of organic fertilizer is very necessary. [3] in his research stated that the provision of $900 \mathrm{~kg} / \mathrm{ha}$ of Palm Oil Long Ash in peat soils could increase soil pH from 4.86 to 5.67 and also increase soil K-dd from $1.16 \mathrm{me} / 100 \mathrm{~g}$ to $5,67 \mathrm{me} / 100 \mathrm{~g}$ and increasing Na-dd of the soil from $2.17 \mathrm{me} / 100 \mathrm{~g}$ to $5.53 \mathrm{me} /$ $100 \mathrm{~g}$ of soil but have not been able to increase Ca-dd and Mg-dd of peat.

Palm oil long Ash is an ameliorant that gives the best results compared to lime ammulorant and volcanic ash in increasing macro $\mathrm{P}, \mathrm{K}, \mathrm{Ca}$ and $\mathrm{Mg}$ nutrient uptake [4]. Provision of 3 tons / ha of AJKS in peat soils can increase the availability of soil $P$ and $\mathrm{K}$ and $\mathrm{pH}$ from 4.0 to 5.12 [5]. [6]. [7] states that visually it is seen that the level of fermented soybean seeds and their color resulting from the AJKS fertilization treatment are richer and cleaner than $\mathrm{KCl}$ fertilization, this is presumably due to the presence of other elements. such as micro elements that are needed in small amounts but have a significant effect on nutrient absorption and protein synthesis. Nutrients contained in AJKS include $\mathrm{K} 2 \mathrm{O}$ as much as $35.0-47 \%$, P2O5 2.3-3.5\%, $\mathrm{MgO} 4.0-6.0 \%$ and $\mathrm{CaO} 4.0-6.0 \%$ and nutrients others (Pahan, 2007). Giving AJKS has the advantage because it contains high potassium, but it can also improve soil $\mathrm{pH}$, and increase soil nutrient availability and soil microorganism activity. Utilization of ash especially AJKS as $\mathrm{K}$ fertilizer is more profitable compared to artificial $\mathrm{K}$ fertilizer based on the following considerations: The price is relatively cheap because of its abundant presence, the main elements in AJKS are $\mathrm{K}, \mathrm{Mg}$ and $\mathrm{Ca}[8], 3$ ) In addition to being able to supply nutrients, ash can also improve soil $\mathrm{pH}$, especially acid soils. From the results of the study [9], [10], [11] the highest yield of dried corn seeds (1.3 tons / ha) was obtained from fertilizer treatment of $250 \mathrm{~kg} /$ ha AJKS on Arjuna varieties and was not significantly different from fertilization treatment $150 \mathrm{~kg} \mathrm{KCl}$ in the Lamuru variety. Of the three varieties tested (Arjuna, Lamuru and Bima varieties), Arjuna varieties were the most adaptive varieties followed by Lamuru and Bima. This can be seen from the level of production, namely Arjuna (1.3 tons / ha), Lamuru (1.1 tons / ha) and Bima 
(0.9 tons / ha). The purpose of this study is to determine the effect of the treatment of oil palm long ash on the growth and production of two varieties of corn (Zea mays $L$ ) on peatlands.

\section{MATERIAL AND METHOD}

The research was carried out in Parit 3 of Tembilahan Hulu Sub-District, Tembilahan Hulu Sub-District, Indragiri Hilir Regency, Riau Province, from October 2017 to March 2018. Initial soil analysis and oil palm long ash (AJKS) analysis were conducted at the Bogor Institute of Agriculture Laboratory, West Java. The materials used in this study were Pioneer corn varieties and N35, oil palm long ash (AJKS) used were taken from palm oil Fresh Fruit Bunch (TBS) processing waste from PT. Bumi Palma Lestari Persada, basic fertilizers used are Urea, SP36, KCL and TSP, the use of dolomite lime to meet the needs of $\mathrm{Ca}$ and $\mathrm{Mg}$ and Azodrin and Dithane M 45 for the prevention of pests and diseases. The tools used are tools used in the field such as hoes, boards, nails, hands of prayer, fat, scales, gauges, calipers, stationery and ropes and tools used in the laboratory. This study uses a randomized block design (RBD) with factorial consisting of:

Factor $\mathrm{A}=\mathrm{AJKS}$ consisting of 4 levels, namely: $\mathrm{A} 0=$ without treatment $\mathrm{AJKS}=0 \mathrm{~kg}$ AJKS $/ \mathrm{ha}, \mathrm{A} 1=0.5$ tons $\mathrm{AJKS} / \mathrm{ha}=$ $500 \mathrm{~kg}$ AJKS $/ \mathrm{ha}, \mathrm{A} 2=1$ ton $A J K S / \mathrm{ha}=1000 \mathrm{~kg}$ AJKS $/ \mathrm{ha}$, $\mathrm{A} 3=1.5$ tons $A J K S / \mathrm{ha}=1500 \mathrm{~kg} \mathrm{AJKS} / \mathrm{ha}$. Factor $\mathrm{V}=$ Varieties consisting of two levels, namely: $\mathrm{V} 1=$ Pioneer Variety and $\mathrm{V} 2$ = Variety $\mathrm{N} 35$, each treatment was repeated three times. Observation parameters include: Plant Height $(\mathrm{cm})$, Dry Weight of Head (gram), Number of cob / Plants (fruit), Cob Weight per Plant (gram), Cob Weight per plot (gram), Cob Diameter $(\mathrm{cm})$, Seed Weight ( gram). Observation data were statistically analyzed by analysis of variance and continued with Tukey HSD test at 5\% level.

\section{RESULT AND DISCUSSION}

\subsection{Chemical Properties of Soil}

The results of the analysis of the initial soil chemical properties (Table 1), showed that the $\mathrm{pH}$ of the peat soils used in this study was included in the moderate $\mathrm{pH}$ criteria which indicated acid soil reactions. Acidic soils are soils with high $\mathrm{H}+$ ion content. Acidic soil reactions cause plants to lack nutrients because at low $\mathrm{pH}$ the nutrient solubility is low so that it is less available and difficult to absorb by plants. Acidity of peat soil is caused by the high content of hydrogen ions resulting from the dissociation of functional groups of organic acids, in line with [11] study that low $\mathrm{pH}$ values are caused by organic acids and exchangeable hydrogen ions and high $\mathrm{H}$-dd contained in peat soils. The results of this study are in line with [12] adding that high organic acids are caused by the decomposition of organic matter, especially in anaerobic conditions which will produce high aliphatic and aromatic acids. Organic acids will experience dissociation $\mathrm{H}$ from functional groups, both carboxyl groups $(-\mathrm{COOH})$ and phenols $(-\mathrm{OH})$. The carboxyl group $(-\mathrm{COOH})$ and the phenol group $(-\mathrm{OH})$ according to this research in harmony with [13] are reactive groups that dominate the exchange complex and can act as weak acids so that they can dissociate and produce large quantities of $\mathrm{H}+$ ions depending on the number of functional groups and degree of dissociation.
Table 1. Results of Analysis of Chemical Properties of Peatlands from Tembilahan Hulu Village, Indragiri Hilir Regency, Riau Province.

\begin{tabular}{|l|l|l|l|l|}
\hline No & \multicolumn{1}{|c|}{ Analisis } & \multicolumn{1}{c|}{ Unit } & \multicolumn{1}{c|}{ Score } & \multicolumn{1}{c|}{ Creteria } \\
\hline 1. & $\mathrm{pH} \mathrm{H} \mathrm{H}_{2} \mathrm{O}(1: 5)$ & & 4,8 & medium \\
2. & $\mathrm{~N}$ total & $\%$ & 0,36 & medium \\
3. & C-Organic & $\%$ & 11,93 & Very hight \\
4. & ash & $\%$ & - & - \\
5. & $\mathrm{C} / \mathrm{N}$ Rasio & & 31 & Very hight \\
6. & $\mathrm{P}$ & $\mathrm{ppm}$ & 22,4 & hight \\
\hline
\end{tabular}

The C-Organic content $(11.93 \%)$ is very high and the $\mathrm{N}$-total $(0.38 \%)$ is classified as moderate, but that does not mean that the needs of $\mathrm{N}$ plants have been fulfilled. Most of $\mathrm{N}$ is in organic form as stated [13] , in peat soils, $N$ is available in less than $3 \%$ and the rest is in the form of complex organic matter that requires mineralization to be used by plants. The availability of $\mathrm{N}$ for plants is related to the $\mathrm{C} / \mathrm{N}$ ratio. From the results of the analysis, the $\mathrm{C} / \mathrm{N}$ ratio of peat soils used in this study was classified as very high (31), where the high $\mathrm{C} / \mathrm{N}$ ratio showed a low level of decomposition. Decomposition of organic material (peat) in anaerobic conditions takes place very slowly and it is assumed that $\mathrm{N}$ soil has been utilized by microorganisms for decomposition energy. This is confirmed by [13] that a $\mathrm{C} / \mathrm{N}$ ratio greater than 30 will cause the $\mathrm{N}$ produced in the mineralization process to be immobilized by micro-organisms for their daily needs. Availability of $\mathrm{P}(22.4$ $\mathrm{ppm}$ ) in the soil from the results of the analysis (table 1 ) is relatively high. The high availability of $P$ in this soil is thought to be due to high organic matter content and low P. fixation capacity. Destruction of organic matter according to [14] will free up a number of N, P and $\mathrm{S}$ in the form available to plants. Generally in peat soils according to [13] most of the $P$ is in the form of organic $\mathrm{P}$ compounds and only a small portion is in the form of inorganic $\mathrm{P}$ compounds, wherein inorganic $\mathrm{P}$ is more correlated with plant needs. Organic $\mathrm{P}$ in the soil according to Tisdale and Nelson [13] will be mineralized by microorganisms into inorganic $P$.

\subsection{The Effect of Giving Palm Oil Long Ashes (AJKS) Against Corn Plants}

Analysis of variance showed that there was no real interaction between the administration of AJKS dosage and varieties, but the main effect of AJKS administration and the main influence of each variety showed significant differences on plant height. The results of the statistical analysis that were further tested with Tukey HSD at the $5 \%$ level are presented in Table 2.

\begin{tabular}{|l|l|l|l|}
\hline \multirow{2}{*}{ Dosage $(\mathrm{kg} / \mathrm{ha})$} & \multicolumn{2}{|c|}{ Main Plots (Varieties) } & \multirow{2}{*}{$\begin{array}{c}\text { Mean Plots Dosage } \\
\text { (AJKS) }\end{array}$} \\
\cline { 2 - 3 } & Pioneer & NK 35 & $114,89 \mathrm{~b}$ \\
500 & 96,67 & 137,33 & $155,67 \mathrm{a}$ \\
1000 & 141,00 & 174,83 & $158,11 \mathrm{a}$ \\
1500 & 153,00 & 168,33 & $164,89 \mathrm{a}$ \\
\hline \multicolumn{1}{|c|}{ Mean Plot } & 160,00 & 163,67 & \\
Varietas & $137,67 \mathrm{~B}$ & $160,92 \mathrm{~A}$ & \\
\hline
\end{tabular}

Note: The numbers followed by the same letter are not significantly different at the $5 \%$ level according to the Tukey HSD test (uppercase is spoken horizontally and lowercase vertically).Table 3 . shows that the administration of AJKS ameliorant increases the height of corn plants on peatlands, with an increase in plant height of $40.78-50.00 \mathrm{~cm}$ compared to without AJKS treatment, but between treatments the AJKS dose is not significantly different. The increase in plant height is due to the addition of nutrient contributions to the soil solution by AJKS thereby increasing the availability of nutrients that can be absorbed by the roots which will then be 
transported to the canopy through xylem vessels. Peat soils that are not given AJKS do not get additional nutrients from AJKS but only from the decomposition of organic matter forming the soil itself. Numerically, there was an increase in plant height at all levels of AJKS administration, this was thought to be caused by increased soil nutrient status due to improved soil pH due to AJKS administration (can be seen in table 2) compared to the initial soil $\mathrm{pH}$ and without AJKS treatment. According to [15] soil pH determines whether or not nutrient elements both macro and micro are absorbed by plant roots. Adequacy of nutrients affects plant growth, one of which is plant height. In addition, plant height growth is also caused by the addition of potassium nutrients contained by AJKS $(223.32 \mathrm{cmol} / \mathrm{kg})$. AJKS analysis results in this study contain high potassium nutrients $(223.32 \mathrm{cmol} / \mathrm{kg})$. [16] stated that naturally potassium diffuses through the soil to the roots of plants that grow in the roots and potassium regions have a significant effect on plant growth. Potassium plays an important role in the early growth of corn plants, especially in the meristem tissue, which is a network that actively divides at the tip. This is in line with the opinion of [17], that the element of potassium plays a more important role in the vegetative growth of plants, especially in the active growing part of the tip meristem (shoots) and there are also in greater numbers in that network compared to the older parts. In addition to the element $\mathrm{K}$ which plays a role in the growth of maize plant height, [18] suggested that the element $P$ is mostly found in plant cells in the form of nucleotide units, while nucleotide is one of the bonds containing $\mathrm{P}$ as a constituent of DNA plays a role in the development of plant cells. [19] states that the increase in plant height is thought to be due to increased levels of available $\mathrm{P}$ and also decreasing $\mathrm{Al}$-dd content which can be toxic to plants. [20] in his research on corn plants found that the higher use of AJKS caused an increase in plant height, number of leaves and stem diameter [21] stated in his research that the administration of AJKS can increase growth in height, leaf length, leaf width, leaf thickness, number of leaves, number of tillers and frond wet weight on aloe vera plants, and concluded that AJKS acts as a source of potassium nutrient. Potassium is very instrumental in stimulating the growth of plant roots. Optimal rooting will support the supply of nutrients into the plant tissue so that it will support the growth of corn plants. Giving K elements from AJKS to plants can affect plant growth, this shows that the $\mathrm{K}$ nutrient plays an important role for plant growth and development. Nutrient $\mathrm{K}$ functions to regulate respiration, transpiration, translocation of carbohydrates, increase resistance to pests and pathogens, improve root systems, plants do not easily fall and provide a balance of excess $\mathrm{N}$. Besides containing $\mathrm{K}$, AJKS also contains other nutrients such as $\mathrm{P}, \mathrm{Cl}$, and $\mathrm{Mg}$, so that with increasing doses, the availability of these nutrients for plants also increases [22]. The increased availability of these nutrients will have an impact on plant growth. The N35 variety showed the highest plant height of $160.92 \mathrm{~cm}$ while the Pioneer variety showed the lowest value $(137.67 \mathrm{~cm})$ of the height of maize on peatlands. This is consistent with the description of corn varieties which show that the N35 variety has a higher plant height $(202 \mathrm{~cm})$ than the Pioneer variety[23].

\section{CONCLUSION}

Of the two varieties used in this study Pioneer varieties have the highest adaptation to peat soils, characterized by high dry weight canopy and seed production. Giving the highest AJKS dose of $1500 \mathrm{~kg} / \mathrm{ha}$ in this experiment proved to be able to increase the growth of corn yield in all parameters except for the number of cob / plant parameters. There was no real interaction and influence between the treatment of AJKS and varieties for all observed parameters.

\section{REFERENCES}

[1] Amaru, Kharistya. 2000. Limbah Industri Kelapa Sawit. Pusat Penelitian Kelapa Sawit. Medan. 3 hal

[2] Asril. 2001. Pertumbuhan dan Hasil Kedelai yang diinukolasi dengan Rhizobium japonicum pada Tanah Gambut Saprik yang diberi Abu Janjang Kelapa Sawit. [Thesis]. Program Pasca Sarjana Universitas Andalas. Padang. $54 \mathrm{Hal}$.

[3] Dai, J. Potensi Gambut Indonesia. Tantangan, Prospek dan Pelestarian. Tanah gambut untuk perluasan pertanian. Proseding seminar; Medan. 27 Nopember 1989. Fakultas Pertanian Universitas Islam Sumatera Utara. Medan. Hal 34.

[4] Djalil. 2003. Subsitusi Pupuk KCL Dengan Abu Janjang Kelapa Sawit Untuk Tanaman Melon [Tesis]. Program Pasca Sarjana Universitas Sumatera Utara. Medan.

[5] Farida, D.E. 1998. Pengaruh Abu Jerami Padi terhadap K tersedia pada tanah ultisol serta Pertumbuhan dan Hasil Kedelai (glycine max L). Skripsi Fakultas Pertanian Universitas Jambi. Jambi.

[6] Gardner, F. P., R. B. Pearce and R. L. Mitchel. 1985. The Physiology Field Crop. Diterjemahkan oleh Susilowati, H. 1991. Fisiologi Tanaman Budidaya. Indonesia Press, Jakarta.

[7] Hakim, N., M. Y. Nyakpa., A. M. Lubis., M. Nugroho., G. Saul., M.A. Diha., M.

[8] Hong., G. B. Bailey. 1986. Dasar-Dasar IImu Tanah. Universitas Lampung.

[9] Lampung. 488 hal.

[10] Hardjowigeno, S. 1996. Pengembangan lahan gambut untuk pertanian. Suatu peluang dan tantangan. Fakultas Pertanian IPB. Bogor. 173 hal.

[11] -------. 1989. Sifat-sifat dan potensi tanah gambut Sumatera untuk pengembangan pertanian. Dalam proseding seminar tanah gambut untuk perluasan pertanian. Fakultas Pertanian Universitas Islam Sumatera Utara. Medan. 309 hal.

[12] Hanibal. 2001. Pengaruh Abu Janjang Kelapa Sawit terhadap Hasil Tanaman Kedelai Pada Ultisol. Jurnal Agronomi Universitas Jambi. Jambi.

[13] Havlin JL, JD Beaton, SL Tisdale and WL Nelson. 2005. Soil Fertility and Fertilizers. An Introduction to Nutrient Management. Seventh Edition. Pearson Education Inc. Upper Saddle River, New Jersey.

[14] Istina, I., N. Umar dan Dorlan. 2007. Pengaruh Limbah Abu Tankos Kelapa Sawit Terhadap Hasil Beberapa Varietas Kedelai Unggul Baru di Lahan PMK. Buletin Inovasi Pertanian. Volume 1. nomor 2. Desembar 2007. 4 hal.

[15] Jones JB, W Benyamin and HA Miliis. 1991. Principles of Plant Nutrition. Internasional Potash Institute. Switzerland.

[16] Kurnianingsih. 2004. Pemanfaatan Lahan Pasang Surut Untuk Budidaya Jagung Manis. [Skripsi]. Fakultas Pertanian Universitas Gadjah Mada. Yogyakarta.

[17] Kasniari dan Supadma. 2007. Pengaruh Abu Janjang Kelapa Sawit Pada Perbaikan Ketersediaan Unsur Makro 
dan Mikro Pada Lahan Gambut . Buletin Media Pertanian UGM. Yogyakarta. Hal 34-42

[18] Lahuddin, 1989. Pengaruh Abu Janjang Kelapa Sawit terhadap B dan Zn tersedia. Buletin I Pertanian USU. Medan. Hal 5-8.

[19] Najiyati, S., L. Muslihat dan I. I. N Suryadiputra. 2005. Panduan Pengelolaan Lahan Gambut untuk Pertanian Berkelanjutan. Proyek Climate Change, Forest and Peatlands in Indonesia. Wetland International. Indonesia Programmeand Wildlife Habitat Canada. Bogor. Indonesia. 9 hal.

[20] Nyakpa, Y. A.M. Lubis, M.A. Pulung, A. Gaffar Amrah, A. Munawar, Go Ban Hong, N. Hakim. 1988. Kesuburan Tanah. Universitas Lampung, Lampung.

[21] Nelvia. 1997. Pemupukan Posphat Alam dan Amelioran pada Tanah Gambut terhadap Ketersediaan dan Serapan P, K, Ca dan Mg oleh tanaman Jagung. Dalam Prosiding Seminar Nasional. Identifikasi Masalah Pupuk Nasional dan Standarisasi Mutu yang Efektif. Bandar Lampung 22 Desember 1997. Kerjasama Unila dan HITI. 132 hal.

[22] Marlina, Sari I. Yusuf E Y, Riono Y, Mulono Apriyanto, 2020. Utilization Of Industrial Waste Pulp And Palm Oil On Growth And Results Of Corn (Zea Mays L) INTERNATIONAL JOURNAL OF SCIENTIFIC \& TECHNOLOGY RESEARCH VOLUME 9, ISSUE 01,

[23] Mulono Apriyanto, M Chairul Basrun Umanailo, 2019. Decrease Polyphenols, Ethanol, Lactic Acid, and Acetic Acid during Fermentation with Addition of Cocoa Beans Innoculum INTERNATIONAL JOURNAL OF SCIENTIFIC \& TECHNOLOGY RESEARCH VOLUME 8, ISSUE 10, OCTOBER/ 